\title{
PRZEKSZTAŁCENIE STOSUNKU SŁUŻBOWEGO FUNKCJONARIUSZY
}

\begin{abstract}
Streszczenie. Przekształcenie stosunku służbowego funkcjonariuszy podlega określonym w przepisach prawa prawidłowościom. Z prawodawstwa wynika również zróżnicowanie podmiotów właściwych do podejmowania określonych czynności prawnych oraz możliwość dokonania ich klasyfikacji.

W opracowaniu poddano analizie treści stosunku służbowego funkcjonariuszy, która dokonana została na bazie ustawodawstwa dotyczącego wybranych służb mundurowych. Pozwoliła ona na wyszczególnienie typowych i charakterystycznych form przekształcenia stosunku służbowego oraz przesłanek, na jakich oparte są zmiany, a także wskazanie, że powszechnym zjawiskiem jest zbieżność terminologiczna. Uzupełnieniem rozważań jest przybliżenie podstawowych terminów, takich jak: funkcjonariusz, służba, mianowanie, powołanie czy stosunek służbowy.
\end{abstract}

Słowa kluczowe: administracja rządowa, służba mundurowa, funkcjonariusz, stosunek służbowy, opiniowanie służbowe.

\section{WSTĘP}

Dokonując rozważań na temat przekształcenia stosunku służbowego funkcjonariuszy, w pierwszej kolejności należy zwrócić uwagę na zróżnicowanie terminologiczne określenia „funkcjonariusz”. Najczęściej mamy do czynienia, zarówno w przepisach prawa, jak i w piśmiennictwie, z pojęciem funkcjonariusza publicznego. Ustawa z dnia 6 czerwca 1997 r. - Kodeks karny (tekst jedn. Dz.U. z 2017 r., poz. 2204 ze zm.) w art. 115 § 13 zawiera definicję funkcjonariusza publicznego i zgodnie z pkt. 7 jest to $\mathrm{m}$.in. funkcjonariusz organu powołanego do ochrony bezpieczeństwa publicznego albo funkcjonariusz Służby Więziennej. Pojęcia tego nie można używać w postępowaniu administracyjnym, gdyż art. 116 k.k. wyraźnie stanowi, że przepisy Kodeksu karnego stosuje się tylko i wyłącznie do ustaw przewidujących odpowiedzialność karną (wyr. NSA z dnia 16 grudnia 2010 r., I OSK 962/10, CBOSA). Powyższa definicja funkcjonariusza publicznego nie odnosi się więc w żaden sposób do statusu zawodowego wymienionych w niej osób, lecz zmierza do osiągnięcia szczególnych celów, takich jak zapewnienie ochrony prawnokarnej osobom zaangażowanym w realizację zadań

* Uniwersytet Rzeszowski, Wydział Prawa i Administracji, Katedra Prawa Policyjnego, hr66@op.pl. 
państwa, ochrony obywateli przed działaniami osób reprezentujących państwo lub działających na jego rzecz albo w jego imieniu (Kuczyński 2011a, 7). Z tego też powodu terminy funkcjonujące $w$ innych aktach prawnych w sposób pełniejszy wkomponowują się w przedmiot dysertacji. Jedna z najszerszych definicji wywodzi się z ustawy z dnia 20 stycznia 2011 r. o odpowiedzialności majątkowej funkcjonariuszy publicznych za rażące naruszenie prawa (art. 2 ust. 1 pkt 1 ustawy; tekst jedn. Dz.U. z 2016 r., poz. 1169), zgodnie z którą pod pojęciem funkcjonariusza publicznego należy rozumieć osobę działającą w charakterze organu administracji publicznej lub z jego upoważnienia albo jako członek kolegialnego organu administracji publicznej lub osobę wykonującą w urzędzie organu administracji publicznej pracę $\mathrm{w}$ ramach stosunku pracy, stosunku służbowego lub umowy cywilnoprawnej, biorącą udział w prowadzeniu sprawy rozstrzyganej w drodze decyzji lub postanowienia przez taki organ. Uwzględniając tę definicję, wyszczególnić należy funkcjonariuszy, których stosunek zatrudnienia regulują przepisy prawa pracy, prawa cywilnego oraz tych, których zatrudnienie przybiera postać stosunku administracyjnoprawnego. Wreszcie „funkcjonariusz” oznacza 'pracownika służb państwowych' (Słownik języka polskiego [b.r.]). W analizowanym aspekcie rozważania zostaną ograniczone do funkcjonariuszy, z którymi nawiązywany jest stosunek służbowy będący formą stosunku administracyjnoprawnego. W tym miejscu należy postawić tezę, że samo przekształcenie stosunku służbowego wywołuje skutek w postaci zmiany sytuacji prawnej funkcjonariusza. Trzeba także założyć, iż przyjęta forma kształtowania statusu służbowego funkcjonariuszy jest najbardziej efektywna i dopasowana do natury służb mundurowych. Przekształcenie stosunku służbowego funkcjonariuszy służb mundurowych następuje w oparciu o tożsame przesłanki i przy wykorzystaniu zbliżonej terminologii.

\section{ISTOTA STOSUNKU ADMINISTRACYJNOPRAWNEGO}

Status funkcjonariusza nabywa się wraz z nawiązaniem stosunku służbowego, a więc mianowaniem (powołaniem) do służby (Stelina 2011, 163). Stosunek administracyjnoprawny jest odmianą stosunku prawnego i powstaje $\mathrm{w}$ wyniku poddania pewnej rzeczywistej działalności regulacji normami prawa administracyjnego. Ma więc charakter władczy, może jednostronnie zdecydować o treści wzajemnych praw lub obowiązków między dwoma podmiotami (Ura 2006, 60). Stosunek administracyjnoprawny stanowi wzajemny układ między dwoma podmiotami - układ zachowań kwalifikowany przez prawo administracyjne (Ura 2006, 61). Według tradycyjnych definicji stosunek administracyjnoprawny ma się wyróżniać spośród innego typu stosunków prawnych nierównością stron (Hauser 2010, 195). Jedną ze stron stosunku administracyjnoprawnego jest organ administracji publicznej, posiadający uprzywilejowaną pozycję wobec drugiej 
strony, którą jest obywatel lub podmiot administrowany. Organ ten posiada prawo do jednostronnego regulowania treści tegoż stosunku w oparciu o przepisy prawa. Szukając swoistych cech stosunku administracyjnoprawnego, określa się jego szczegółowe elementy, a więc: przedmiot i podmioty stosunku, układy stosunków między podmiotami, a także, jako element dodatkowy, dokonuje się porównań tego stosunku z innymi stosunkami prawnymi (Hauser 2010, 195). Odnosząc się do rodzajów stosunków administracyjnoprawnych, współczesna literatura najczęściej wskazuje na: materialnoprawne, procesowe, do których zaliczyć należy także stosunki egzekucyjne, spornoadministracyjne, nadzoru oraz stosunki wynikające z układów zależności organizacyjnej. Relacjami opartymi na układach zależności organizacyjnej są stosunki służbowe nawiązywane na podstawie nominacji i podporządkowania pracownika względem przełożonego (Ura, Ura 2006, 47). W tej kwestii Roman Hauser podziela pogląd prezentowany przez Zbigniewa Leońskiego, że są to

stosunki służbowe pracownika oparte na nominacji, gdzie mamy do czynienia z podporządkowaniem wewnętrznym aktom (poleceniom służbowym czy instrukcjom) wydawanym tylko na podstawie norm kompetencyjnych i stosunki zakładowe, w których użytkownik zakładu podlega władztwu zakładowemu (Hauser 2010, 202).

Istotne znaczenie $\mathrm{w}$ analizowanym aspekcie ma nawiązanie stosunku administracyjnoprawnego. Ustalenia doktryny są w zasadzie zgodne i wynika z nich, że stosunki administracyjnoprawne mogą powstać z mocy prawa i z mocy decyzji organu administracji publicznej (Hauser 2010, 209). W doktrynie również występuje podział tych relacji na: materialne, procesowe, ustrojowe, nadzoru i służbowe. Służbowe to stosunki zależności służbowej i podporządkowania pracownika względem przełożonego, uregulowane są przede wszystkim w statutach i regulaminach organów administracji publicznej lub podmiotów wykonujących funkcje administracyjne (Szczęch 2013, 26).

\section{STOSUNEK SLUŻBOWY}

Stosunkami opartymi na układach zależności organizacyjnej są stosunki służbowe nawiązywane na podstawie nominacji i podporządkowania pracownika względem przełożonego (Ura 2011, 66). Są to stosunki administracyjnoprawne powstające przez mianowanie na podstawie dobrowolnego zgłoszenia się do służby, a ustające z chwilą doręczenia lub ustnego ogłoszenia decyzji o ich rozwiązaniu bądź z chwilą zajścia zdarzenia, które je rozwiązuje (Dzimińska-Mosio 2001, 304). Ich treścią są prawa i obowiązki stron, a przedmiotem zachowanie wymagane od osoby zobowiązanej, odniesione do treści służby (Kuczyński 2011a, 7). W doktrynie za podstawę wyodrębnienia stosunku służbowego najczęściej przyjmuje się kryterium formalne i merytoryczne. Zgodnie z kryterium 
formalnym za osoby pozostające w stosunku służbowym, najogólniej mówiąc, można by uznać tylko osoby zatrudnione zawodowo i odpłatnie w formacjach, dla których statusu w języku prawnym zachowano pojęcie służby i stosunku służbowego (Kuczyński 2011a, 8). Tę grupę osób stanowią z pewnością sędziowie i prokuratorzy oraz funkcjonariusze służb mundurowych, w tym służb specjalnych. $\mathrm{Na}$ treść tych relacji, jak się przyjmuje, składają się wzajemne prawa i obowiązki stron niemające charakteru zobowiązaniowego (Liwo 2013, 288). Dla stosunków służbowych, będących podstawą pełnienia służby w określonej formacji mundurowej i uzbrojonej, cechą szczególną jest podległość służbowa, która sprawia, że w stosunku służbowym nie występuje równorzędność podmiotów typowa dla zobowiązaniowego stosunku pracy (Ura 2013, 278). Kryterium merytoryczne natomiast, zdaniem Tadeusza Kuczyńskiego, „zakłada [...] konieczność analizowania właściwości danego stosunku prawnego na podstawie różnic i podobieństw do ustalonego wzorca i wyprowadzanie wniosków stosownie do wyników tej analizy" (Kuczyński 2011a, 8). Cechą charakterystyczną jest tu pełna dyspozycyjność funkcjonariusza, wynikająca z możliwości jednostronnego regulowania przez władzę służbową wszystkich najistotniejszych składników treści stosunku służbowego (Nowakowski i in. 2009, 164).

Dokonując analizy pragmatyki sędziów i prokuratorów, należy stwierdzić, że przepisy odnoszące się do ich stosunku zatrudnienia są niejednolite oraz ma w nich zastosowanie zróżnicowana terminologia. W niektórych uregulowaniach jest wprost mowa, że prokurator pozostaje w stosunku służbowym, zaś inne przepisy ustawy Prawo o prokuraturze mówią o stosunku pracy, o czym świadczy również droga sądowa odnosząca się do roszczeń z tego stosunku¹. Obowiązująca ustawa z dnia 27 lipca 2001 r. Prawo o ustroju sądów powszechnych (tekst jedn. Dz.U. z 2018 r., poz. 23 ze zm.)

wprawdzie konsekwentnie stanowi, że sędzia pozostaje w „stosunku służbowym”, jednakże analiza jej treści nie pozostawia wątpliwości, że sędzia, podobnie jak prokurator, pozostaje w stosunku składającym się z norm wyznaczających służbową (publiczną) sferę jego statusu, określającą relacje $\mathrm{z}$ organem niebędącym pracodawcą, np. w związku z aktem powierzenia lub utraty urzędu (stanowiska), stosowaniem zarówno odpowiedzialności dyscyplinarnej, jak i norm wytyczających sferę zobowiązaniową, określającą relacje między nim a sądem działającym za pośrednictwem właściwego organu jako przedstawiciela ustawowego pracodawcy w zakresie nawiązywania i rozwiązania więzi pracowniczej oraz norm zobowiązaniowych określających bezpośrednie, operatywne stosunki między nim a zatrudniającym go sądem jako pracodawcą (Kuczyński 2011a, 9-10).

O pracowniczym, a nie służbowym charakterze stosunku sędziego świadczą m.in. takie zwroty, jak: „,zas pracy”, a nie „czas służby”, „wynagrodzenie

${ }^{1}$ Przykładowe przepisy mówiące o stosunku służbowym prokuratora to: art. $91 \S 1,93 \S 3$ i 6 , $96 \S 2 . \mathrm{Z}$ art. $99 \mathrm{i}$ art. $101 \S 1$ ustawy z dnia 28 stycznia 2016 r. Prawo o prokuraturze (tekst jedn. Dz.U. z 2017 r., poz. 1767 ze zm.) wynika, że zatrudnienie prokuratora ma charakter stosunku pracy. 
za pracę”, a nie „uposażenie za służbę”, „dodatek za wieloletnią pracę”, a nie „służbę”, „wypadek przy pracy”, a nie „w służbie” itp. (Kuczyński 2011a, 10). Konstrukcja przepisów dotyczących stosunku zatrudnienia prokuratorów i sędziów wskazuje na jego służbowo-pracowniczy charakter. W przypadku służb mundurowych nie widać rozbieżności terminologicznej, a normy prawne zawarte w ustawach ustrojowych jednoznacznie wskazują na treść stosunku służbowego, pomimo że oprócz prawa publicznego również prawo konstytucyjne czy też prawo pracy jest dostrzegalne przy kształtowaniu stosunku tegoż zatrudnienia funkcjonariuszy. Oznacza to, że nie są oni pracownikami w rozumieniu ustawy z dnia 26 czerwca 1974 r. Kodeks pracy (tekst jedn. Dz.U. z 2018 r., poz. 917 ze zm.; dalej: k.p.), którzy świadczyliby pracę na podstawie stosunku zobowiązaniowego. Funkcjonariusz nie jest więc pracownikiem w rozumieniu art. 2 k.p. i nie ma wobec niego zastosowania zasada subsydiarnego stosowania przepisów Kodeksu pracy na mocy ogólnej klauzuli zawartej w art. 5 k.p.; mogą natomiast mieć zastosowanie jedynie w zakresie wymienionym w przepisie szczególnym (Ura 2013, 278).

W przepisach prawa występuje też pojęcie służby jako zatrudnienia w formacjach wyspecjalizowanych, wykonujących funkcje publiczne (Ura 2011, 19). Uwzględniając kryterium zakresu odniesienia rozwiązań przyjętych w pragmatykach do koncepcji ,służby” w ujęciu formalnym i instytucjonalnym oraz koncepcji „,pracy” rozumianej jako stosunek zobowiązaniowy normowany przez prawo pracy (prawo zobowiązań), można rozważane stosunki podzielić na dwie podstawowe grupy:

1) stosunki służbowe służb zbrojnych zmilitaryzowanych (mundurowych),

2) pracownicze stosunki służbowe (Kuczyński 2011a, 13).

Biorąc pod uwagę powyższe ustalenia oraz fakt, że jedną z najważniejszych funkcji publicznych jest zapewnienie bezpieczeństwa i porządku publicznego, analiza przekształcenia stosunku służbowego oparta została na przepisach materialnoprawnych, odnoszących się do największych i najważniejszych z tej perspektywy służb. Z pewnością wśród służb mundurowych, których stosunek zatrudnienia i jego przekształcenie poddany został reżimom administracyjnoprawnym, są: Policja, Straż Graniczna, Agencja Bezpieczeństwa Wewnętrznego i Agencja Wywiadu, Centralne Biuro Antykorupcyjne, Służba Ochrony Państwa oraz Państwowa Straż Pożarna. W tych formacjach służbę pełnią funkcjonariusze oraz pracownicy pozostający w stosunku pracy. Pragmatyki w tym względzie wprowadzają różne formy zatrudnienia, takie jak mianowanie, powołanie, czy umowa o pracę. W interesującym nas aspekcie ciężar badawczy położony został na dwie pierwsze formy stosunku służbowego. Praca w służbach mundurowych podejmowana jest bowiem na podstawie aktu mianowania (powołania) dobrowolnie i bez przymusu pozostawania w niej po rozpoczęciu (Liwo 2013, 286). 


\section{MIANOWANIE I POWOLANIE SEUŻBOWE}

W nauce prawa administracyjnego mianowanie jest traktowane jako akt administracyjny, jednostronnie rozstrzygający w indywidualnej sprawie, powodujący powierzenie stanowiska i nawiązanie stosunku służby (Wojtunik 2013, 204). Funkcjonariusze służb mundurowych zatrudniani są z reguły na mocy aktu mianowania lub, w niektórych sytuacjach, aktu powołania, mającego różnorodny charakter prawny, uzależnionego od skutków i jego trybu. Przy różnorodności poglądów zasadne wydaje się stanowisko, zgodnie z którym charakter prawny aktu mianowania nie może być oceniany w oderwaniu od sfery, w której ta podstawa stosunku pracy funkcjonuje (Dubowik, Pisarczyk 2011, 86). Należy jednak zwrócić uwagę na to, że zarówno mianowanie, jak i powołanie, bez względu na ich podstawę (wynikającą z przepisów prawa pracy i przepisów pozakodeksowych), są aktami formalnie jednostronnymi, mimo dobrowolności zgłoszenia się do służby (pracy) i złożonym oświadczeniem woli o zamiarze dobrowolnego zatrudnienia (Liwo 2013, 313). Stosunek pracy na podstawie mianowania może zostać nawiązany, jeżeli wynika to z ustawy, a nie z woli stron (Dubowik, Pisarczyk 2011, 86). W kwestii sposobu określenia organu właściwego do podjęcia aktu mianowania (oraz nominacyjnego) w służbach mundurowych panuje zróżnicowanie kompetencyjne (Liwo 2013, 286). Czynności związane ze stosunkiem służbowym wykonują odpowiednie organy służbowe, stosownie do kompetencji przypisanych im w pragmatykach służbowych. W przypadku służb mundurowych zauważalne są dwie tendencje: jedna polega na skupianiu kompetencji do mianowania w rękach szefa danej służby (CBA, ABW i AW, SOP, wojskowe służby specjalne), druga polega na przekazaniu uprawnień na niższe szczeble w hierarchii organów danej służby (Policja, Państwowa Straż Pożarna, Straż Graniczna, czy Służba Więzienna). Organy te działają jednak w imieniu danej służby i w imieniu państwa, którego częścią przecież jest określona formacja (Stelina 2011, 162). Drugą stroną stosunku służbowego natomiast jest funkcjonariusz będący osobą fizyczną, który spełnia wskazane w przepisach prawa (pragmatykach służbowych) warunki do ubiegania się o przyjęcie do służby. Zaznaczyć przy tym trzeba, że status funkcjonariusza nabywa się z chwilą nawiązania stosunku służbowego, najczęściej na mocy aktu mianowania. Większość pragmatyk służbowych jako podstawę nawiązania stosunku służbowego wskazuje właśnie akt mianowania. O administracyjnoprawnym charakterze mianowania świadczy nie nazwa nawiązanego rodzaju zatrudnienia, ale jego elementy, wskazujące na nierównorzędność stron stosunku prawnego (Ura 2013, 281). W obecnym stanie prawnym wyróżnić można dwa rodzaje mianowania:

pracownicze, stanowiące podstawę stosunku pracy m.in. w administracji publicznej oraz mianowanie służbowe, będące podstawą tzw. stosunków służbowych, w jakich pozostają żołnierze oraz funkcjonariusze służb zmilitaryzowanych (Policji, Straży Granicznej, Służby Więziennej, AW, ABW) (Stelina 2013, 185). 
Ustawy kształtujące ustrój służb mundurowych dokonują rozgraniczenia na różne rodzaje mianowania, do których zaliczyć należy mianowanie na okres służby kontraktowej, kandydackiej, przygotowawczej i na stałe. Pierwszy akt mianowania rodzi skutki w postaci nawiązania stosunku służbowego. Co do kolejnych aktów można mówić o rozwiązaniu dotychczasowego stosunku i nawiązaniu nowego lub przekształceniu dotychczasowego zatrudnienia $\mathrm{z}$ terminowego na bezterminowe, np. mianowanie w służbie stałej. Kontekst normatywny omawianego zagadnienia, w tym regulacja przypadków ustania stosunku służbowego, jak również stosowana przez ustawodawcę terminologia (używanie nazwy „stosunek służbowy" w liczbie pojedynczej) i wreszcie względy pragmatyczne skłaniają do opowiedzenia się za drugim z wymienionych wariantów (Stelina 2011, 183184). Biorąc powyższe pod uwagę, należy przyjąć, że kolejne akty mianowania, co do zasady, prowadzą do przekształcenia stosunku służbowego funkcjonariusza. Mianowanie jako pojęcie z języka prawnego występuje w pragmatykach w co najmniej dwojakim znaczeniu - raz jako podstawa nawiązania lub przekształcenia stosunku służbowego (nazywana wobec żołnierzy zawodowych powołaniem), innym razem jako akt nadania stopnia służbowego (Stelina 2011, 183). Mianowanie na określony stopień służbowy jest czynnością o charakterze organizacyjnym, powodującą zmianę statusu funkcjonariusza, będącą zarazem zmianą treści jego stosunku służbowego.

Obok mianowania w pragmatykach służbowych w szerokim zakresie wykorzystuje się także akty powołania (odwołania) jako czynności organizacyjne związane z obsadą najwyższych stanowisk w poszczególnych służbach (Stelina 2011, 182). W świetle niektórych przepisów powołanie w ogóle nie odnosi się do podstawy nawiązania stosunku pracy, a oznacza jedynie powierzenie określonych kompetencji lub funkcji pracownikowi lub osobie niebędącej pracownikiem, $\mathrm{w}$ innych zaś wypadkach pod pojęciem powołania ukrywa się w istocie mianowanie na stanowisko (Dubowik, Pisarczyk 2011, 89). W praktyce można spotkać się z powołaniem, które powoduje nawiązanie stosunku zatrudnienia - osoba nie jest funkcjonariuszem, oraz z powołaniem na stanowisko kierownicze, które nie powoduje nawiązania stosunku służbowego - osoba pozostająca w służbie (Jaworski 2016, 82). Powołanie jest czynnością prawną o charakterze jednostronnym, wywołującą jednak dwojakiego rodzaju skutki prawne: organizacyjno-prawne i obligacyjne (Stelina 2011, 208). Skutek organizacyjno-prawny powstaje przy powołaniu np. na określone stanowisko kierownicze, zaś w sferze obligacyjnej to nawiązanie stosunku zatrudnienia. Przykładem nawiązania stosunku służbowego na mocy aktu powołania jest powołanie do służby żołnierza zawodowego². Występują sytuacje, w których przepisy prawa zezwalają na powołanie na stanowisko

${ }^{2}$ Zgodnie z art. 9 ust. 4 ustawy z dnia 11 września 2003 r. o służbie wojskowej żołnierzy zawodowych (tekst jedn. Dz.U. z 2018 r., poz. 173 ze zm.) stosunek służbowy żołnierza służby stałej powstaje w drodze powołania na podstawie dobrowolnego zgłoszenia się do tej służby. 
kierownicze, przeważnie szefa danej formacji, osoby niepozostającej w czynnej służbie, np. ustawa o Policji nie ogranicza możliwości powołania na stanowisko Komendanta Głównego tylko i wyłącznie policjantów. Stąd należy przyjąć, że akt powołania rodzi dwa skutki prawne: jeden w sferze służbowej - powstanie stosunku służbowego, drugi w sferze organizacyjnej - powstanie stosunku organizacyjnego, kierowniczego (Stelina 2011, 183). Powołanie czy też odwołanie ze stanowiska kierowniczego pełnienia funkcji organu ma charakter czynności organizacyjnej, nie następuje tu więc nawiązanie lub rozwiązanie stosunku służbowego. Odwołanie ze stanowiska nie wpływa na ciągłość stosunku służbowego i z reguły jego konsekwencją jest powrót na poprzednio zajmowane stanowisko lub w przypadku braku możliwości powrotu - mianowanie na równorzędne. Analiza pragmatyk służbowych pozwala na wysnucie wniosku, że w chwili obecnej akt powołania (odwołania) jest podstawą do przekształcenia stosunku służbowego adresata tego aktu.

\section{FORMY PRZEKSZTALCENIA STOSUNKU SLUŻBOWEGO}

Nawiązanie, zmiana (przekształcenie) oraz rozwiązanie stosunku służbowego następuje poprzez wydanie decyzji administracyjnej, która przybiera postać rozkazu personalnego, wywołującego skutek prawny uzależniony od konstrukcji przepisu materialnoprawnego. Do spraw z zakresu zmiany stosunku służbowego zakwalifikować należy:

1) sprawy zmian w zakresie stanowiska służbowego,

2) sprawy zmian w zakresie stopnia służbowego,

3) sprawy zmian w zakresie miejsca pełnienia służby (siedziby służbowej),

4) sprawy zmian w zakresie stałych świadczeń pieniężnych ze stosunku służbowego,

5) sprawy zmian miejsca lub charakteru pełnienia służby,

6) sprawy prowadzone w trybach nadzwyczajnych przez organy nadzoru jurysdykcyjnego kształtujące lub zmieniające elementy stosunku służbowego, w tym sprawy o wznowienie postępowania lub stwierdzenie nieważności decyzji o zwolnieniu ze służby ze skutkiem przywrócenia do służby (Maciejko, Korcz-Maciejko 2010, 52).

Wobec tych stosunków niezwykle istotny charakter mają te, które zachodzą w toku służby i polegają na wykonywaniu różnych funkcji (Liwo 2013, 292). Podstawy prawne zatrudnienia i przekształcenia stosunku służbowego w służbach mundurowych wynikają z wielu ustaw regulujących funkcjonowanie służb, w kwestiach szczegółowych odsyłających do przepisów wykonawczych, $\mathrm{z}$ reguły rozporządzeń właściwego ministra. Ustawy ustrojowe dotyczące służb mundurowych zawierają zróżnicowane uregulowania prawne odnoszące się do przekształcenia stosunku służbowego ich funkcjonariuszy. Jako przykładowe 
podstawy prawne, dotyczące przekształcenia stosunku służbowego funkcjonariuszy oraz właściwości przełożonych w tych sprawach, wskazać należy: art. 32 ust. 1, art. 36 ust. 1, art. 38 ust. 1, art. 39 ust. 1 ustawy z dnia 6 kwietnia 1990 r. o Policji (tekst jedn. Dz.U. 2019, poz. 161 ze zm.) ${ }^{3}$; art. 36 ust. 1, art. 40 ust. 1, art. 42 ust. 1, art. 43 ust. 1 ustawy z dnia 12 października 1990 r. o Straży Granicznej (tekst jedn. Dz.U. z 2019 r., poz. 147 ze zm.) ${ }^{4}$; art. 32 ust. 1, 37c ust. 1 i 2 , art. 38 ust. 1, art. 39 ust. 1 ustawy z dnia 24 sierpnia 1991 r. o Państwowej Straży Pożarnej (tekst jedn. Dz.U. z 2018 r., poz. 1313) ${ }^{5}$; art. 78 ust. 1, art. 102 ust. 1, art. 103 ust. 1 ustawy z dnia 17 stycznia 2018 r. o Służbie Ochrony Państwa

${ }^{3}$ Art. 32 ust. 1: Do mianowania policjanta na stanowiska służbowe, przenoszenia oraz zwalniania z tych stanowisk właściwi są przełożeni: Komendant Główny Policji, Komendant CBŚP, Komendant BSWP, komendanci wojewódzcy i powiatowi (miejscy) Policji oraz komendanci szkół policyjnych.

Art. 36 ust. 1: Policjant może być przeniesiony do pełnienia służby albo delegowany do czasowego pełnienia służby w innej jednostce organizacyjnej Policji lub w innej miejscowości z urzędu lub na własną prośbę.

Art. 38 ust. 1: Policjanta przenosi się na niższe stanowisko służbowe w razie wymierzenia kary dyscyplinarnej wyznaczenia na niższe stanowisko służbowe.

Art. 39 ust. 1: Policjanta zawiesza się w czynnościach służbowych w razie wszczęcia przeciwko niemu postępowania karnego w sprawie o przestępstwo lub przestępstwo skarbowe, umyślne, ścigane z oskarżenia publicznego - na czas nie dłuższy niż 3 miesiące.

${ }^{4}$ Art. 36 ust. 1: Do mianowania funkcjonariusza na stanowisko służbowe, przenoszenia na inne stanowisko oraz zwalniania z tego stanowiska właściwi są przełożeni: Komendant Główny Straży Granicznej, Komendant BSWSG, komendanci oddziałów Straży Granicznej, komendanci ośrodków szkolenia Straży Granicznej oraz komendanci ośrodków Straży Granicznej.

Art. 40 ust. 1: Funkcjonariusz może być przeniesiony do pełnienia służby albo delegowany do czasowego pełnienia służby w innej jednostce organizacyjnej Straży Granicznej lub innej miejscowości z urzędu lub na własną prośbę.

Art. 42 ust. 1: Funkcjonariusza przenosi się na niższe stanowisko służbowe w razie wymierzenia kary dyscyplinarnej wyznaczenia na niższe stanowisko służbowe.

Art. 43 ust. 1: Funkcjonariusza zawiesza się w czynnościach służbowych na okres nie dłuższy niż 3 miesiące w razie jego tymczasowego aresztowania lub wszczęcia przeciwko niemu postępowania karnego w sprawie o przestępstwo umyślne ścigane $\mathrm{z}$ oskarżenia publicznego lub przestępstwo skarbowe umyślne. Jeżeli okres tymczasowego aresztowania jest dłuższy niż 3 miesiące, zawieszenie ulega z mocy prawa przedłużeniu do czasu zakończenia tymczasowego aresztowania.

${ }^{5}$ Art. 32 ust. 1: Do mianowania strażaka na stanowisko służbowe, przenoszenia na inne, powierzania pełnienia obowiązków służbowych na innym stanowisku, zawieszania w czynnościach służbowych albo zwalniania ze służby, z zastrzeżeniem art. 47 ust. 1, właściwi są przełożeni: 1) w Komendzie Głównej - Komendant Główny; 2) w komendzie wojewódzkiej - komendant wojewódzki; 3) w komendzie powiatowej (miejskiej) - komendant powiatowy (miejski); 4) (uchylony); 5) w Szkole Głównej Służby Pożarniczej i pozostałych szkołach - komendant szkoły; 6) w jednostce badawczo-rozwojowej - dyrektor jednostki; 7) (uchylony); 8) w Centralnym Muzeum Pożarnictwa - dyrektor muzeum.

Art. 37c ust. 1: Strażak może być przeniesiony do pełnienia służby w innej miejscowości na własny wniosek lub za jego zgodą. 2. Strażak może być przeniesiony z urzędu do pełnienia służby w innej jednostce organizacyjnej w tej samej miejscowości. 
(Dz.U. z 2018 r., poz. 138 ze zm.) ${ }^{6}$; art. 54 ust. 1, art. 59 ust. 1, art. 61 ust. 1, art. 62 ust. 1 ustawy z dnia 9 czerwca 2006 r. o Centralnym Biurze Antykorupcyjnym (tekst jedn. Dz.U. z 2018 r., poz. 2104 ze zm.) ${ }^{7}$; art. 50 ust. 1, art. 55 ust. 1, art. 57 ust. 1, art. 58 ust. 1 ustawy z dnia 24 maja 2002 r. o Agencji Bezpieczeństwa Wewnętrznego oraz Agencji Wywiadu (tekst jedn. Dz.U. z 2018 r., poz. 2387 ze zm. $)^{8}$. Są to uregulowania prawne odnoszące się w sposób fragmentaryczny do analizowanej problematyki, jednakże ze względu na ich podobieństwa w przepisach pragmatycznych wydaje się, iż w sposób adekwatny odzwierciedlają możliwości dokonywania zmian stosunku służbowego funkcjonariuszy.

Art. 38 ust. 1: Strażaka przenosi się na niższe stanowisko służbowe w razie: 1) wymierzenia kary dyscyplinarnej wyznaczenia na niższe stanowisko służbowe; 2) zawinionej utraty uprawnień koniecznych do wykonywania czynności na zajmowanym stanowisku.

Art. 39 ust. 1: Strażaka zawiesza się w czynnościach służbowych, na czas nie dłuższy niż 3 miesiące, w razie wszczęcia przeciwko niemu postępowania karnego w sprawie o przestępstwo umyślne ścigane z oskarżenia publicznego lub przestępstwo skarbowe umyślne.

${ }^{6}$ Art. 78 ust. 1: Wyznaczenie funkcjonariusza na stanowisko służbowe, przenoszenie oraz zwalnianie $\mathrm{z}$ tych stanowisk następuje na podstawie rozkazu personalnego Komendanta SOP.

Art. 102 ust. 1: Funkcjonariusza przenosi się na niższe stanowisko służbowe w przypadku wymierzenia kary dyscyplinarnej wyznaczenia na niższe stanowisko służbowe.

Art. 103 ust. 1: Funkcjonariusza zawiesza się w czynnościach służbowych w razie wszczęcia przeciwko niemu postępowania karnego o przestępstwo umyślne ścigane z oskarżenia publicznego, na czas nie dłuższy niż 3 miesiące.

${ }^{7}$ Art. 54 ust. 1: Szef CBA jest właściwy do przyjmowania do służby w CBA, mianowania funkcjonariuszy na stanowiska służbowe oraz ich przenoszenia, delegowania, oddelegowania, zwalniania i odwoływania ze stanowisk służbowych, zawieszania i uchylania zawieszenia w czynnościach służbowych, zwalniania ze służby oraz stwierdzania wygaśnięcia stosunku służbowego.

Art. 59 ust. 1: Funkcjonariusz z urzędu lub na własną prośbę może być przeniesiony do pełnienia służby albo delegowany na okres do 6 miesięcy do czasowego pełnienia służby w innej miejscowości.

Art. 61 ust. 1: Funkcjonariusza przenosi się na niższe stanowisko służbowe w przypadku wymierzenia kary dyscyplinarnej wyznaczenia na niższe stanowisko służbowe.

Art. 62 ust. 1: Funkcjonariusza zawiesza się w czynnościach służbowych, na czas nie dłuższy niż 3 miesiące, w przypadku wszczęcia przeciwko niemu postępowania karnego w sprawie o przestępstwo umyślne ścigane z oskarżenia publicznego lub przestępstwa skarbowe.

${ }^{8}$ Art. 50 ust. 1: Szef ABW i Szef AW, każdy w zakresie swojego działania, jest właściwy do przyjmowania do służby w Agencji, mianowania funkcjonariuszy na stanowiska służbowe oraz ich przenoszenia, delegowania, oddelegowania, zwalniania i odwoływania ze stanowisk służbowych, zawieszania i uchylania zawieszenia w czynnościach służbowych, zwalniania ze służby oraz stwierdzania wygaśnięcia stosunku służbowego.

Art. 55 ust. 1: Funkcjonariusz z urzędu lub na własną prośbę może być przeniesiony do pełnienia służby albo delegowany na okres do 6 miesięcy do czasowego pełnienia służby w innej miejscowości.

Art. 57 ust. 1: Funkcjonariusza przenosi się na niższe stanowisko służbowe w razie wymierzenia kary dyscyplinarnej wyznaczenia na niższe stanowisko służbowe.

Art. 58 ust. 1: Funkcjonariusza zawiesza się, rozkazem personalnym, w czynnościach służbowych, na czas nie dłuższy niż 3 miesiące, w razie wszczęcia przeciwko niemu postępowania karnego w sprawie o przestępstwo umyślne ścigane z oskarżenia publicznego. 
W tym miejscu zauważyć należy, że przekształcenie stosunku służbowego może mieć różnorakie podłoże. U podstaw rozważanej zmiany mogą leżeć zarówno zmiany stanu prawnego prowadzące do przekształcenia treści stosunku pracy (służby) z mocy prawa, jak i modyfikacje wynikające z czynności i zdarzeń prawnych (Kuczyński 2011b, 227). Zmiana stosunku służbowego funkcjonariuszy podlega określonym w przepisach prawa prawidłowościom, zauważalne jest także zróżnicowanie podmiotów właściwych do podejmowania określonych czynności prawnych, istnieje również możliwość dokonania pewnej klasyfikacji przekształceń tegoż stosunku.

W sensie przedmiotowym wskazana zmiana odnosi się do możności dokonywania przez właściwy podmiot $\mathrm{w}$ drodze czynności prawnej przekształceń treści stosunku zatrudnienia w zakresie miejsca pracy/ służby, rodzaju pracy/ stanowiska służbowego, wynagrodzenia/ uposażenia (Kuczyński 2011b, 227). Do kwestii związanych z przekształceniem stosunku służbowego niewątpliwie zaliczyć należy także udzielenie urlopu bezpłatnego, czy zawieszenie w czynnościach służbowych funkcjonariuszy. Taki ich status wywołuje konieczność znacznie zwiększonej dyspozycyjności służbowej, głęboko sięgającej dyscypliny służbowej oraz przesądza o władczym, administracyjnym charakterze rozkazów, poleceń służbowych i innych aktów kształtujących stosunek pomiędzy organem zatrudniającym (przełożonym służbowym) a zatrudnionym funkcjonariuszem (Maciejko 2008, 154).

Zmiana miejsca pełnienia służby może nastąpić w wyniku delegowania do innej miejscowości, przy czym akt będący podstawą tego działania leży w sferze organizacyjnej i nie ma charakteru trwałego oraz nie ulegają zmianie składniki uposażenia, dlatego nie przybiera on postaci zaskarżalnej decyzji administracyjnej. O wiele powszechniej stosowaną formą zmiany miejsca pełnienia służby jest przeniesienie do innej jednostki organizacyjnej lub innej miejscowości. W ujęciu procesowym zmiany treści stosunku zatrudnienia w wyniku przeniesienia przybierają postać formalnie i materialnie jednostronnych albo formalnie jednostronnych, a materialnie dwustronnych aktów prawnych przełożonego, modyfikujących treść stosunku zatrudnienia (Kuczyński 2011b, 227). Zmiany jednostronne wynikają z władztwa, jakim został obdarzony przełożony właściwy do przeniesienia oraz podstawy materialnoprawnej do podjęcia takiego działania, co jest charakterystyczne dla formacji mundurowych. Niezależnie od tego, z czyjej inicjatywy następuje przekształcenie stosunku służbowego, np. oświadczenia woli funkcjonariusza czy też decyzji przełożonego, konkretyzowane jest ono formie jednostronnego aktu administracyjnego.

Przekształcenie stosunku służbowego może nastąpić także poprzez mianowanie na inne nowe stanowisko służbowe. Kolejne mianowania powodują zmianę (przekształcenie) stosunku służbowego, tj. ustanie dotychczasowego i nawiązanie stosunku na nowych warunkach, np. mianowanie na inne stanowisko służbowe (Jaworski 2016, 81). Z reguły mianowanie na stanowisko służbowe dotyczy 
wyższych lub równorzędnych stanowisk, chociaż przepisy prawa przewidują również możliwości mianowania na niższe stanowisko. Mianowanie na niższe stanowisko może nastąpić na prośbę funkcjonariusza, w sytuacji zmian organizacyjnych przy braku możliwości zapewnienia stanowiska równorzędnego, pogorszenia się stanu zdrowia uniemożliwiającego pełnienie służby na dotychczas zajmowanym oraz wymierzenia kary dyscyplinarnej wyznaczenia na niższe stanowisko służbowe. Treść stosunku służbowego w takich sytuacjach ulega zmianie niezależnie od podstaw dokonanej zmiany. Zmiana treści stosunku zatrudnienia odnosi się do praw i obowiązków jego stron (Kuczyński 2011b, 227). Przy określaniu obowiązków funkcjonariusza na danym stanowisku kształtowane są również nowe składniki wynagrodzenia, np. mnożnik kwoty bazowej i dodatki. Ze zmianą stanowiska związana jest zmiana uposażenia, które w przeważającej większości ustalane jest $\mathrm{w}$ akcie mianowania na określone stanowisko służbowe.

Jedna z możliwości zmiany stosunku służbowego funkcjonariuszy wynika z nałożenia kary dyscyplinarnej wyznaczenia na niższe stanowisko, czy też z obniżenia stopnia służbowego. Do istoty regulacji dotyczących funkcjonariuszy należy zaliczyć to, że uprawomocnienie się kary dyscyplinarnej nie powoduje samoistnego skutku zmiany treści stosunku służbowego, lecz zobowiązuje przełożonego do podjęcia aktu prawnego modyfikującego ukaranemu funkcjonariuszowi stosunek służby jako obligatoryjnego aktu wykonania orzeczenia dyscyplinarnego (Kuczyński 2011b, 250). Skutkiem wydania takowej decyzji jest zmiana warunków finansowych zatrudnienia, ponieważ ulega obniżeniu uposażenie zasadnicze oraz dodatek za posiadany stopień służbowy w przypadku jego obniżenia.

Sytuacje, w których następuje obniżenie stopnia należą do rzadkości, znacznie częściej modyfikacja treści stosunku służbowego ma miejsce w przypadku mianowania na wyższy stopień służbowy. Przepisy pragmatyk służbowych określają tryb i warunki takiego mianowania, z reguły jest to kryterium stażu służby w określonym stopniu oraz przypisanie wyższego stopnia do zajmowanego stanowiska, a także pozytywna opinia służbowa. Zmiana ta łączy się z wyższą gratyfikacją oraz powoduje niekiedy przyporządkowanie funkcjonariusza do wyższego korpusu, co jest związane z pewnym awansem w hierarchii służbowej. Jednakże decyzja w tym względzie jest uznaniowa i należy do przełożonego właściwego do mianowania na określony stopień służbowy.

Kolejną formą, wprawdzie specyficzną, przekształcenia stosunku służbowego funkcjonariuszy jest zawieszenie w czynnościach służbowych. Polega ona na odsunięciu funkcjonariusza od wykonywania obowiązków służbowych na czas określony w decyzji lub do zakończenia postępowania będącego podstawą do zastosowania tego środka. Instytucja zawieszenia w obowiązkach jest analizowana zarówno w kontekście zmiany treści stosunku zatrudnienia, jak i odpowiedzialności (sankcji) dyscyplinarnej (Kuczyński 2011b, 234). Konsekwencją zawieszenia w czynnościach oprócz okresowej zmiany treści stosunku służbowego jest również zawieszenie z reguły $50 \%$ ostatnio należnego uposażenia. Zmiana taka 
może również wynikać ze zdarzenia prawnego i stanowić konsekwencję wydanego przez prokuratora postanowienia o zastosowaniu środka zapobiegawczego w postaci zawieszenia w czynnościach służbowych funkcjonariusza.

Analizując problematykę przekształcenia stosunku służbowego, trzeba również zwrócić uwagę na możliwość korzystania przez funkcjonariuszy z urlopu bezpłatnego. Jest to prawo funkcjonariusza, z którego może korzystać po wyrażeniu zgody przez właściwego przełożonego. Zgoda na urlop bezpłatny z reguły nie przybiera postaci aktu administracyjnego i ma charakter czasowy. Cechą charakterystyczną jest utrata $\mathrm{w}$ okresie przebywania na tym urlopie przez funkcjonariusza uprawnień do pobierania uposażenia i niekiedy innych świadczeń wynikających ze służby.

W niektórych pragmatykach można spotkać się z instytucją przeniesienia z jednej formacji do innej służby mundurowej. Szczególnie rozbudowany katalog służb, z których mogą być przenoszeni funkcjonariusze znajduje się w ustawie o Policji i w ustawie o Straży Granicznej ${ }^{10}$. Przenoszona osoba przestaje pełnić służbę w dotychczasowej formacji i staje się funkcjonariuszem nowej służby. Przepisy nie wskazują, czy następuje rozwiązanie jednego stosunku i nawiązanie nowego, czy też stosunek służbowy ulega przekształceniu poprzez zmianę ,pracodawcy". Ustawodawca określił, że takiemu funkcjonariuszowi nie przysługuje odprawa oraz inne należności związane z odejściem ze służby oraz że zachowuje ciągłość służby, równorzędny stopień służbowy i nie musi składać na nowo ślubowania, stąd wniosek, że jest to jedna z możliwości przekształcenia stosunku służbowego.

\section{WNIOSKI}

Analiza treści stosunku służbowego funkcjonariuszy dokonana na bazie ustawodawstwa dotyczącego wybranych służb mundurowych pozwoliła na wyszczególnienie typowych i charakterystycznych form jego przekształcenia. Zauważalnym zjawiskiem jest zbieżność terminologiczna oraz przesłanki, na jakich oparte są zmiany. Cechą odróżniającą zaś jest zróżnicowanie organów właściwych

${ }^{9}$ Zgodnie z art. 25a ustawy o Policji: Funkcjonariusz Straży Granicznej, Służby Ochrony Państwa, Służby Celno-Skarbowej, Państwowej Straży Pożarnej, Agencji Bezpieczeństwa Wewnętrznego, Agencji Wywiadu, Służby Wywiadu Wojskowego, Służby Kontrwywiadu Wojskowego lub Centralnego Biura Antykorupcyjnego może być na własną prośbę przeniesiony do służby w Policji, jeżeli wykazuje on szczególne predyspozycje do jej pełnienia.

${ }^{10}$ Zgodnie z art. 31a ustawy o Straży Granicznej: Funkcjonariusz Policji, Służby Ochrony Państwa, Służby Celno-Skarbowej, Państwowej Straży Pożarnej, Agencji Bezpieczeństwa Wewnętrznego, Agencji Wywiadu, Służby Wywiadu Wojskowego, Służby Kontrwywiadu Wojskowego lub Centralnego Biura Antykorupcyjnego może być na własną prośbę przeniesiony do służby w Straży Granicznej, jeżeli wykazuje on szczególne predyspozycje do jej pełnienia. 
do dokonywania czynności prawnych skutkujących przekształceniem stosunku służbowego, co z uwagi na organizację poszczególnych służb wydaje się w pełni uzasadnione. Niewątpliwie samo przekształcenie stosunku służbowego wywołuje skutek w postaci zmiany sytuacji prawnej funkcjonariusza. Na podstawie analizy materiału źródłowego należy również stwierdzić, że przyjęty sposób przekształcenia stosunku służbowego utrwalony został w przedstawionych służbach i spełnia swoją rolę. Konstatując, wskazać jednak trzeba, że szereg podobieństw w kształtowaniu stosunku służbowego i w jego przekształceniu jest argumentem przemawiającym za podjęciem próby ustanowienia ustawy pragmatycznej, która obowiązywałaby wybrane formacje oraz prowadziła do kompleksowego ujednolicenia i uproszczenia przepisów „prawa stosunków służbowych”.

\section{BIBLIOGRAFIA}

Dubowik, Anna, Łukasz Pisarczyk. 2011. Prawo urzędnicze. Warszawa: Lex a Wolters Kluwer business.

Dzimińska-Mosio, Monika. 2001. „Funkcjonariusz Policji”. W Leksykon policyjny. Red. Wiesław Pływaczewski, Grażyna Kędzierska. 304. Szczytno: Wydawnictwo Wyższej Szkoły Policji w Szczytnie.

Hauser, Roman. 2010. „Stosunek administracyjnoprawny”. W System prawa administracyjnego. T. 1: Instytucje prawa administracyjnego. Red. Roman Hauser, Zygmunt Niewiadomski, Andrzej Wróbel. 195-202. Warszawa: Wydawnictwo C.H. Beck, Instytut Nauk Prawnych PAN.

Jaworski, Bogdan. 2016. Pozycja prawna Komendanta Głównego Policji jako centralnego organu administracji rzadowej. Rzeszów: ZPH Arteks.

Kuczyński, Tadeusz. 2011a. „Pojęcie i przedmiot prawa stosunków służbowych”. W System prawa administracyjnego. T. 11: Stosunek stużbowy. Red. Roman Hauser, Zygmunt Niewiadomski, Andrzej Wróbel. 1-52. Warszawa: Wydawnictwo C.H. Beck, Instytut Nauk Prawnych PAN.

Kuczyński, Tadeusz. 2011b. „Zmiana stosunku zatrudnienia”. W System prawa administracyjnego. T. 11: Stosunek stużbowy. Red. Roman Hauser, Zygmunt Niewiadomski, Andrzej Wróbel. 227-251. Warszawa: Wydawnictwo C.H. Beck, Instytut Nauk Prawnych PAN.

Liwo, Marian. 2013. Status stużb mundurowych i funkcjonariuszy w nich zatrudnionych. Warszawa: LexisNexis.

Maciejko, Wojciech. 2008. Osobowe prawo administracyjne. Warszawa: Wydawnictwo C.H. Beck.

Maciejko, Wojciech, Aneta Korcz-Maciejko. 2010. Postępowanie w sprawach osobowych w Policji. Wrocław: Gaskor.

Nowakowski, Zdzisław, Marta Pomykała, Jan Rajchel, Kazimierz Rajchel, Henryk Tokarski. 2009. Administracja bezpieczeństwa i porządku publicznego. Warszawa: Towarzystwo Naukowe Powszechne.

Słownik języka polskiego. [b.r.]. „Funkcjonariusz” [hasło]. Pwn.pl. http://sjp.pwn.pl/slowniki/funkcjonariusz.html [dostęp 18.12.2017].

Stelina, Jakub. 2011. „Strony i nawiązanie stosunków służbowych”. W System prawa administracyjnego. T. 11: Stosunek stużbowy. Red. Roman Hauser, Zygmunt Niewiadomski, Andrzej Wróbel. 163-208. Warszawa: Wydawnictwo C.H. Beck, Instytut Nauk Prawnych PAN.

Stelina, Jakub. 2013. Prawo urzędnicze. Wyd. 2. Warszawa: Wydawnictwo C.H. Beck.

Szczęch, Norbert. 2013. „Administracja publiczna i prawo administracyjne”. W Administracja publiczna i prawo administracyjne w zarysie. Red. Mirosław Karpiuk, Jerzy Kowalski. 15-27. Warszawa-Poznań: Polskie Wydawnictwo Prawnicze „Iuris”. 
Ura, Elżbieta. 2006. Zagadnienia prawa administracyjnego i funkcjonowania administracji publicznej. Przemyśl: Mitel.

Ura, Elżbieta. 2011. Prawo urzędnicze. Wyd. 3. Warszawa: LexisNexis.

Ura, Elżbieta. 2013. „Charakter prawny stosunku służbowego policjanta”. Zeszyty Naukowe Wyższej Szkoły Informatyki, Zarzadzania i Administracji w Warszawie 2 (23): 277-283.

Ura, Elżbieta, Edward Ura. 2006. Prawo administracyjne. Wyd. 6. Warszawa: LexisNexis.

Wojtunik, Piotr. 2013. „Pojęcie, źródła i przedmiot prawa stosunków służbowych”. Przegląd Bezpieczeństwa Wewnętrznego 8 (5): 202-217.

\title{
Akty prawne
}

Ustawa z dnia 26 czerwca 1974 r. Kodeks pracy (tekst jedn. Dz.U. z 2018 r., poz. 917 ze zm.).

Ustawa z dnia 6 kwietnia 1990 r. o Policji (tekst jedn. Dz.U. z 2019 r., poz. 161 ze zm.).

Ustawa z dnia 12 października 1990 r. o Straży Granicznej (tekst jedn. Dz.U. z 2019 r., poz. 147 ze zm.).

Ustawa z dnia 24 sierpnia 1991 r. o Państwowej Straży Pożarnej (tekst jedn. Dz.U. z 2018 r., poz. 1313).

Ustawa z dnia 24 maja 2002 r. o Agencji Bezpieczeństwa Wewnętrznego oraz Agencji Wywiadu (tekst jedn. Dz.U. z 2018 r., poz. 2387 ze zm.).

Ustawa z dnia 11 września 2003 r. o służbie wojskowej żołnierzy zawodowych (tekst jedn. Dz.U. z 2018 r., poz. 173 ze zm.).

Ustawa z dnia 9 czerwca 2006 r. o Centralnym Biurze Antykorupcyjnym (tekst jedn. Dz.U. z 2018 r., poz. 2104 ze zm.).

Ustawa z dnia 20 stycznia 2011 r. o odpowiedzialności majątkowej funkcjonariuszy publicznych za rażące naruszenie prawa (tekst jedn. Dz.U. z 2016 r., poz. 1169).

Ustawa z dnia 28 stycznia 2016 r. Prawo o prokuraturze (tekst jedn. Dz.U. z 2017 r., poz. 1767 ze zm.). Ustawa z dnia 17 stycznia 2018 r. o Służbie Ochrony Państwa (Dz.U. z 2018 r., poz. 138 ze zm.).

\section{Orzecznictwo}

Wyrok Naczelnego Sądu Administracyjnego z dnia 16 grudnia 2010 r., sygn. akt I OSK 962/10, CBOSA.

\section{Bogdan Jaworski}

\section{TRANSFORMATION OF MUTUAL RELATIONS OF OFFICERS}

\begin{abstract}
Transformation of official mutual relations of public servants is subject to some regularities in legal provisions. Differentiation of subjects appropriate to take some acts in law is noticeable, but there is also a possibility of making a classification of some changes.

In the article, the content of the officers' service relationship was analysed basing on legislation concerning selected uniformed services. It allowed specifying the typical and characteristic forms of transforming the service relationship and the premises on which the changes are based as well as indicating that a typical phenomenon is terminological convergence. A supplement to the considerations is presentation of basic concepts, such as an officer, service, nomination, appointment or a business relationship.
\end{abstract}

Keywords: governmental administration, uniformed services, officer, business relations, service review. 